\title{
The Effectiveness of Criminal Case Trials in Indonesian Courts Electronically in the Era of the Covid-19 Pandemic
}

\author{
Arif $\mathrm{Abdi}^{1}$, Suparno $^{2}$ \\ \{arifabdiharahap@yahoo.co.id ${ }^{1}$, suparno@borobudur.ac.id² \\ Universitas Borobudur, Jakarta, Indonesia ${ }^{1,2}$
}

\begin{abstract}
The Covid-19 pandemic enormously affects individuals' lives, both monetarily and socially, and the legal executive is no special case, particularly the preliminary of criminal cases in Indonesian courts. The issue in this review is the way compelling the preliminary of criminal cases in Indonesian courts electronically in the period of the Coronavirus pandemic is. The motivation behind this composing is to give a comprehension of how the adequacy of the criminal case preliminary framework as managed in Supreme Court Regulation No. 4 of 2020 concerning the Administration and Trial of Criminal Cases in Courts Electronically. This paper uses normative and empirical research methods with a field study approach with qualitative analysis. The results of this study show how the trial process for criminal cases in the Court is carried out electronically or online via teleconference, where this is a strategy advancement made by the Supreme Court of the Republic of Indonesia. Consequently, the preliminary of criminal cases can in any case run by focusing on wellbeing conventions in the time of globalization of Coronavirus pandemic. The study reveals that technical efforts are still needed to support the implementation of the trial electronically, in order to achieve a fair trial and fulfill the rights of the accused and to fulfill human rights and criminal proceedings based on the Criminal Procedure Code. Among others, in the examination of defendants and witnesses in criminal cases. There is still a need to improve adequate facilities and infrastructure to support the implementation of criminal case trials to fulfill the basic rights of the accused as well as to fulfill a sense of justice (access to justice).
\end{abstract}

Keywords: Covid-19; E-Court; Justice

\section{Introduction}

The development of Corona Virus Disease (Covid-19) toward the finish of 2019 which was then formally declared as a worldwide pandemic by the World Health Organization (WHO) on March 11, 2020.1,[1] had an impact on most countries in the world, including Indonesia. The impact caused by COVID-19 affects the life of social interaction in society. This is because of the execution of social limitations as illustrated in Government Regulation No. 21 of 2020 which controls the execution of Large-Scale Social Restrictions set by the 
Minister of Health and can be done by Regional Governments dependent on the endorsement of the Minister of Health. This Government Regulation alludes to Law Number 6 of 2018 concerning Health Quarantine where this Law manages the Purpose of Health Quarantine; Responsibilities of the Central Government and Regional Governments in shielding general wellbeing from illnesses and additionally Public Health Risk Factors that cause Public Health Emergency through the execution of Quarantine; the type of freedoms and commitments of the local area in wellbeing quarantine; Investigation; and Criminal Provisions for the people who abuse.

The adverse consequence likewise influences the legal executive in Indonesia, so the Supreme Court should give a forward leap as a Circular, particularly in regards to the change of the preliminary example in court, particularly for criminal situations where preliminaries were recently directed traditionally or eye to eye and must be led on the web, from a distance or by video chat. [2]

Article 1 number 12 of the Supreme Court Regulation Number 4 of 2020 concerning Administration and Trial of Criminal Cases in Courts Electronically states "Electronic preliminary is a progression of cycles to inspect, attempt, and settle on the litigant's case by the Court which is completed by the Court with the help of data innovation and general media correspondence and other electronic means". As to guideline, the Supreme Court gave a Circular Letter of the Supreme Court Number 1 of 2020 concerning Guidelines for the Implementation of Duties During the Period of Prevention of the Spread of Corona Virus Disease (Covid-19) inside the Supreme Court and Judicial Bodies Under It, Circular Letter of the Supreme Court Number 6 of 2020 concerning the Working System inside the Supreme Court and Judicial Bodies Under it in the New Normal Order and the Letter of the Director General of the General Judiciary Agency Number 379/DJU/PS.00/3/2020 of 2020 concerning Criminal Case Trials by Teleconference.

With regards to executing these guidelines, an arrangement was made between law requirement offices as laid out in the Cooperation Agreement between the Supreme Court of the Republic of Indonesia, the Attorney General's Office of the Republic of Indonesia, and the Ministry of Law and Human Rights of the Republic of Indonesia Number 402/DJU/KM.01.1/4/2020. , KEP-17/E/Ejp/04/2020, PAS-08.HH.05.05 Year of 2020 with respect to Trials Through Teleconference, which changes the preliminary interaction which was recently completed face to face in court to be on the web.

\section{Methods}

The problem in this research is: How to discuss the trial process for criminal cases in court during the Covid-19 pandemic?

\subsection{Research Method}

The kind of exploration utilized in this review is regularizing exact legitimate examination, which utilizes library materials both essential information and optional information, essential information utilized in this review is as composed positive lawful arrangements that applied to lawful occasions in concreto in the public eye.[3] While the secondary data used are all sources that can be used as references to explain further from primary data in the form of articles, journals, literatures and relevant research results. Information assortment was brought out by field examines through perception, while information investigation was done 
subjectively to acquire replies to the issues in the exploration.

\subsection{Writing Systematics}

The discussion in this paper is organized into three parts, as follows:

1. Introduction. Contains background, problem formulation, research methods and writing systematics.

2. Discussion, Contains a description of the trial process in criminal cases in court and the obstacles found.

3. Closing, Contains conclusions and suggestions

\section{Discussion}

The Covid-19 pandemic that hit nations on the planet arose toward the finish of 2019 and started to be identified in Indonesia in mid 2020, where the positive instance of Covid-19 was declared straight by the President of the Republic of Indonesia, Joko Widodo on March 2, 2020.[4] In light of this, the Government of the Republic of Indonesia gave a Government Regulation Number 21 of 2020 concerning Large-Scale Social Restrictions (PSBB) in the Context of Accelerating the Handling of Corona Virus Disease 2019 (Covid-19) which manages the execution of enormous scope social limitations. The sum is controlled by the Minister of Health and can be completed by the Regional Government dependent on the endorsement of the Minister of Health. By and by, this constraint of exercises extraordinarily influences the exhibition of government establishments and private bodies, remembering court foundations for doing preliminary cycles at all levels of the court.

With regards to carrying out friendly separating, court organizations can't hold preliminaries as specified in the procedural law since it can cause swarms and possibly increment the spread of the COVID-19 infection. The utilization of data innovation assets after the issuance of Supreme Court Regulation Number 4 of 2020 concerning Administration and Trial of Criminal Cases in Courts Electronically turns into an answer for legitimate administrations to equity seekers. Though indeed, it isn't new for the Supreme Court to be prepared to hold far off web-based preliminaries or video chats, in light of the fact that the Supreme Court has turned into the primary State High Institution to apply innovation in each viewpoint and line of its legal administrations. Beginning from the introduction of the SIPP application, e-Court, and e-Litigation which briefly have practical experience in common cases.[5]

In PERMA Number 4 of 2020 concerning Administration and Trial of Criminal Cases in Courts Electronically, the component for the organization and preliminary of criminal cases directed online is controlled, which incorporate:[6]

\subsection{Trial Preparation}

Article 7 paragraph (1) to paragraph (8) explains the preparation process that must be passed, starting from checking by the Registrar/Substitute Registrar on the readiness of the trial participants, the presence of the defendant and his legal advisor, the presence of IT officers and staff who are allowed to attend according to regulations. legislation and the availability of adequate recording equipment/cameras/CCTV. 


\subsection{Indictments and Objections}

It is regulated in Article 8 to Article 9 which states that if the trial is conducted online, then the objection/exception document is sent to the Judge/Judge Council and the file is forwarded to the Public Prosecutor in the form of Portable Document Format (PDF) sent to the court's electronic postal address hearing the case before it is read and verified between what is read and what is downloaded. The equivalent applies to the assessment of the Public Prosecutor against the respondent's protest/special case. Likewise it is feasible to articulate the interlocutory judgment on the web.

\subsection{Examination of Witnesses and Experts}

In Article 11 paragraph it is stated that the examination of Witnesses and/or Experts is carried out in the Court's courtroom even though the trial is conducted electronically, but under certain conditions the judge may determine the examination of Witnesses and/or Experts in other places in accordance with the laws and regulations. Meanwhile, Article 12 explains regarding the examination of witnesses whose identities according to the legislation or according to the Panel of Judges must be kept confidential, witness statements are displayed in audio format without displaying video features or carried out without the presence of the defendant.

\subsection{Examination of the Defendant}

Article 13 regulates the mechanism for examining defendants in accordance with statutory regulations with electronic trial facilities provided.

\subsection{Evidence Inspection}

In Article 14 it is stated that the evidence to be examined remains at the office of the Prosecutor and is shown electronically, in the event that the evidence in the form of a printed document by the judge matches the scanned document with the original document shown. Meanwhile, in the event that the evidence is not in the form of a document, it can be photographed or videoed and sent to the court's e-mail address in the trial before being submitted as evidence.

\subsection{Claims, Defenses, Replies and Duplicates}

In Article 15 it is explained as in Article 3 that the documents of criminal charges, defenses, replicas and duplicates are sent to the court's e-mail address before being read out, and after being read out, the documents are sent to the e-mail address of the Public Prosecutor/defendant and/or Legal Counsel.

\subsection{Verdict and Notification of Decision}

In Article 16 it is explained that in certain circumstances based on the determination of the Judge / Panel of Judges, the hearing of the pronouncement of the decision can be held electronically and then it can be delivered by the court to the defendant via e-mail, Whatsapp or SMS (short message service) address, by registered letter to the residence of the defendant. 
or through the mass media, bulletin boards and court pages.

The preliminary system as expressed above, with respect to online criminal case preliminaries isn't managed in the Criminal Procedure Code, yet as another option, PERMA is an answer in completing the preliminary interaction during the COVID-19 pandemic. Since all things considered, with regards to ensuring basic freedoms, the lawful cycle for respondents should in any case be done as it ought to. In the Criminal Procedure Code, the rule of quick, basic and minimal expense equity is known, as controlled in Article 50 passage (1) which peruses: "A suspect has the option to promptly get an assessment by a specialist and would then be able to be submitted to the public examiner." furthermore, this standard is likewise managed in Law no. 48 of 2009 concerning Judicial Power which states "Judicials are done basically, rapidly, and for minimal price." "Basic" implies that the assessment and settlement of cases is completed in a proficient and compelling way. In the mean time, "Low expense" signifies the expense of the case that can be reached by general society at large. With respect to "Fast" signifies "right away". A fast preliminary is particularly required, particularly to stay away from long detainment under the watchful eye of an adjudicator's choice is made. Hence, the presence of PERMA Number 4 of 2020 concerning Administration and Trial of Criminal Cases in Courts Electronically is a type of convenience to this standard.

In practice, the online trial process does not escape the obstacles or problems that accompany it, including:

1. The issue of the preliminary being available to the general population and Cyber Security As a type of straightforwardness in the criminal equity preliminary, Article 153 passage (3) of the Criminal Procedure Code peruses: "For the motivations behind the assessment, the adjudicator, the executive of the preliminary, opens the preliminary and proclaims that it is available to people in general, besides in cases concerning goodness, or the litigant is a kid." comparable to the web-based preliminary which is communicated through live streaming, which is sure to give admittance to everybody to observe the procedures, including by witnesses who have not been inspected, so they know the declarations of different observers. This obviously disregards the standards contained in Article 159 passage (1) of the Criminal Procedure Code which expresses those witnesses may not speak with one another prior to giving declaration. Likewise, the public's unlimited admittance to online preliminary shows make the chance of hacking or obstruction by reckless gatherings. This will surely be a significant issue with regards to huge and complex matters. It doesn't preclude the chance of significant reports and court procedures being hacked for specific purposes.

2. The issue of access to assistance, PERMA Number 4 of 2020 concerning Administration and Trial of Criminal Cases in Courts Electronically specifies that lawful guidance can be in a similar spot as the respondent, yet then again, there are rules from different foundations, for example, detainment facilities or confinement houses that are not uniform so it isn't workable for legitimate insight and the litigant is in a similar room.

3. Potential for declining quality of testimony and/or evidence, in light of Article 11 passage (3) PERMA Number 4 of 2020 concerning Administration and Trial of Criminal Cases in Court Electronically that witnesses can give data from a foreordained spot by the Judge/Judge Council, this can possibly cause intercession or strain on the observer or the respondent which can influence their declaration. Moreover, the assessment of proof helped out through filtered archive documents, photographs and recordings may not really give total data on the object of the proof.

4. Judge's Confidence Issue, Online proof, in the implementation of an online criminal case trial, the judge decides with a minimum of 2 (two) pieces of evidence and adds the judge's 
conviction. In this case, the Judge found it difficult to catch it. There is still considerable doubt for the Judge's conviction because the material truth is the most important and becomes difficult when going through an online trial.[7]

\subsection{Technical Issues and Human Resources}

Many technical and human resource problems are still encountered in online criminal court proceedings, based on the monitoring carried out by the Ombudsman of the Republic of Indonesia (ORI) of 16 (sixteen) District Courts which in its report stated:

"...The holding of this virtual preliminary has the potential for maladministration, specifically an extended deferral. This is shown by discoveries, for example, its absence staff assets. Restricted IT work force influence virtual preliminary arrangement to be slow, particularly in case there are specialized snags in the preliminary. The indistinct planning of the preliminary, restricted offices and foundation, for example, restricted courts that have video chat gear. An unsteady web network likewise can possibly create extended setbacks for the preliminary cycle. The FGD between the Ombudsman of the Republic of Indonesia and a few Legal Aid Organizations $(\mathrm{OBH})$ brought about a few realities identified with issues in lead of virtual courts. Specialized impediments were viewed as like restricted control of innovation by judges, helpless coordination between parties, legitimate consultants not being one next to the other with the respondent and incapable to guarantee that observers and litigants were feeling the squeeze/lie..."[8]

Therefore, technical issues and human resources can be mapped in the online criminal case trial process, including: a. Lack of IT staff resources; b. Limited facilities and infrastructure; c. Unstable internet network; d. Limitations of judges in terms of mastery of technology; e. Poor coordination between parties. Problems related to technical and human resources are considered quite influential on the quality of evidence and the quality of the trial. As an illustration, in the examination process where the internet network condition is unstable, the questions submitted are not clearly heard by the witness or defendant, and vice versa, the information given by the witness or defendant in an unstable internet network condition will sound unclear to the Judge/Judge Council. This is one of the factors that will affect the quality of the trial in the end. On the issues mentioned, it will be a challenge for the Judge/Judge Council in deciding the case by prioritizing its objectivity based on the facts presented during the trial.

\section{Conclusion}

From the conversation depicted above, it tends to be presumed that the issuance of PERMA Number 4 of 2020 concerning Administration and Trial of Criminal Cases in Courts Electronically is an advancement made by the Supreme Court to change the law in the domain of criminal procedural law to oblige the continuation of court procedures in cases criminal equity and give lawful conviction over the web-based preliminary instrument, albeit in its application it gives two elective court procedures, either disconnected or straightforwardly or on the web. The presence of PERMA Number 4 of 2020 concerning Administration and Trial of Criminal Cases in Courts Electronically, gives a genuine picture that legal foundations in Indonesia have put forth attempts to ensure the security of legal chairmen and gatherings who are the subject of the preliminary interaction during the COVID-19 pandemic as the execution of the guideline of individuals' wellbeing is the most noteworthy law or "salus papuli lex esto" 
(Cicero, 106-43 BC). However, in practice, the online criminal case trial process in courts in Indonesia still encounters various obstacles which include: cyber security constraints, obstacles to access to assistance, the potential for decreasing the quality of testimony and/or evidence, judges' beliefs issues as well as technical issues and human resources. This is a challenge for judicial institutions and other law enforcement institutions to make improvements so that the online trial mechanism can be maintained as an instrument for the process of resolving cases in court.

With regards to legitimate and legal change, it is considered significant to complete changes and advancements identified with the internet based criminal case preliminary interaction which is done extensively and exhaustively to try not to cover guidelines and lawful ambiguities that happen identified with the preliminary course of criminal cases in court, other than that it is important to expand the limit of HR in court organizations in regards to the control and utilization of data innovation (IT).

\section{Reference}

[1] https://www.kompas.com/sains/read/2020/03/12/083129823/who-resmi-sebut-virus-coronacovid-19-sebagai-pandemi-global?page=all (Accessed on October, 7, 2021).

[2] Wahyu Iswantoro, Persidangan Pidana secara Online, Respon Cepat MA Hadapi PandemiCovid-19, Jurnal Selisik, Volume 6, No 1, Juni 2020, hlm 57.

[3] Abdulkadir Muhammad, 2004, Hukum dan Penelitian Hukum, Jakarta, Citra Aditya Bakti,hlm 52.

[4] https://indonesia.go.id/narasi/indonesia-dalam-angka/ekonomi/kasus-covid-19pertama-masyarakat-jangan-panik (diakses tanggal 8 Okteber 2021)

[5] Iswantoro, Op.Cit., hlm 62.

[6] Peraturan Mahkamah Agung Nomor 4 Tahun 2020 tentang Administrasi Dan PersidanganPerkara Pidana Di Pengadilan Secara Elektronik

[7] Munhamir Ihwana Ahmadi, dkk, Efektivitas Persidangan Online Perkara Pidana Pada Masa Pandemi Covid-19 Terhadap Objektivitas Hakim (Studi Kasus di Pengadilan Negeri Surabaya Kelas I.A Khusus) Jurnal Dinamika, Volume 27, No. 16, Juli 2021, Hlm 2351.

[8] Ombudsman Republik Indonesia (ORI), Kajian Cepat/Rapid Assesment Potensi Maladministrasi Pada Penyelenggaraan Persidangan Online di Tengah Pandemi, Laporan, 2020. Hlm16-17 